\title{
Primary production of microphytobenthos in the Ems-Dollard Estuary*
}

\author{
Franciscus Colijn and Victor N. de Jonge
}

Biological Research Ems-Dollard Estuary (BOEDE), Marine Botany Research Group, University of Groningen, Kerklaan 30, 7511 NN Haren, The Netherlands

\begin{abstract}
From 1976 through 1978 primary production of microphytobenthos was measured at 6 stations on intertidal flats in the Ems-Dollard estuary using the ${ }^{14} \mathrm{C}$ method. The purpose of the measurements was to estimate the annual primary production at different sites in the estuary and to investigate the factors that influence the rates of primary production. Therefore benthic chlorophyll $a$ and a set of environmental factors were measured. Only primary production correlated significantly with chlorophyll a concentration in the superficial $(0.5 \mathrm{~cm})$ sediment layer; other factors (temperature, in situ irradiance) did not correlate with primary production, primary production rate or assimilation number. Annual primary production ranged from ca. $50 \mathrm{~g} \mathrm{C} \mathrm{m}^{-2}$ to $250 \mathrm{~g} \mathrm{C} \mathrm{m}^{-2}$ and was closely related to elevation of the tidal flat station. However, highest values were also recorded at the station closest to a waste water discharge point in the inner part of the estuary. Annual primary production can be roughly estimated from the mean annual content of chlorophyll $a$ in the sediment. Use of different calculation methods results in annual primary production values that do not differ greatly from each other. Also productivity rates did not differ much over most of the estuary, except at the innermost station which showed a high production rate in combination with high microalgal biomass; this could not be explained by the high elevation of the station alone. A hypothesis is offered to explain the limited primary production of microphytobenthic vegetations.
\end{abstract}

\section{INTRODUCTION}

The radio carbon $\left({ }^{14} \mathrm{C}\right)$ method (Steemann Nielsen, 1952), although subject to several errors (cf. Colijn et al., 1983) (for review see Peterson, 1980), has been widely adopted to measure phytoplankton primary production in different habitats. With modifications, this method has also been used several times for the measurement of phytobenthos primary production in intertidal areas and shallow coastal seas (Grøntved, 1960; Steele and Baird, 1968; Gargas, 1970; Leach, 1970; Cadée and Hegeman, 1974, 1977; Plante-Cuny, 1978). In other, similar habitats, primary production has further been measured by means of the oxygen bell-jar technique (Pomeroy, 1959; Pamatmat, 1968; Van Es, 1982a; Lindeboom and De Bree, 1982). All these studies aimed essentially at estimating annual primary production and community respiration (in case of oxygen method) and at explaining how these processes are affected by abiotic and biotic factors.

\footnotetext{
- Publication No. 68 of the project 'Biological Research in the Ems-Dollard Estuary' (BOEDE)
}

The soft, sandy and muddy, sediments of the EmsDollard estuary do not harbour a conspicuous vegetation of macroalgae; however, a thin film of diatoms and cyanobacteria covers the sediment surface. These are the main primary producers on intertidal flats (Cadée and Hegeman, 1974; Admiraal, 1980; Colijn and Dijkema, 1981). The purpose of our study was to measure in situ photoautotrophic carbon fixation of sediments at different sites. The programme included measuring chlorophyll a content of the superficial layers of sediment; solar radiation; temperature; salinity; tidal emersion during daylight; and characterization of the type of sediment. Considerable effort was devoted to estimating the annual primary production, which can be calculated using a combination of data on tidal emersion and daylight periods. Physiological experiments and field investigations on benthic diatoms from the same estuary were made by Admiraal (1977a, b, c) and Admiraal and Peletier (1980). Results of recent measurements of primary production in the same estuary obtained with the oxygen method, were also available (Van Es, 1982a).

In addition to the factors that directly regulate prim- 
ary production - such as light and nutrients - we were also interested in the effects of indirect factors - such as grazing, burial, tansport, sedimentation, suspension and mortality of microphytobenthos and phytoplankton. Measurements of both phytoplanktic and microphytobenthic production (Colijn, 1978) should elucidate the quantitative importance of organic matter input derived from primary producers in the EmsDollard ecosystem as opposed to the allochthonic organic matter input from the North Sea (cf. de Jonge and Postma, 1974), the river Ems and the river Westerwoldsche A (Van Es, 1982b).

\section{MATERIAL AND METHODS}

\section{Area and sampling stations}

The Ems-Dollard estuary (Fig. 1) is one of the larger estuaries in the Wadden Sea. A particular feature of this estuary is the Dollard, a shallow protected embayment into which the Westerwoldsche A discharges only small amounts of freshwater, loaded with high concentrations of organic matter. For our research, measurements were regularly taken at 6 stations on intertidal flats (Fig. 1); all stations, except Station 2, diameter and $15 \mathrm{~cm}$ long, as described by Leach (1970). Immediately after being mixed with 2 to $20 \mu \mathrm{C}{ }^{14} \mathrm{C}, 50$ $\mathrm{ml}$ water was carefully added to each cylinder through a rubber cap. Remaining air was expelled by pressing the cylinders more deeply into the sediment. The incubators were kept in the sediment for 2 to $3 \mathrm{~h}$. The incubation water was obtained from shallow pools on the tidal flats or from nearby gullies. Following the incubation period, the cylinders were brought to the laboratory or the research vessel in a dark box and processed within $1 \mathrm{~h}$. Inorganic carbon was measured in the incubation water according to the method of Strickland and Parsons (1972). The added amount of ${ }^{14} \mathrm{C}$ was determined threefold. Light and dark serum bottles containing $50 \mathrm{ml}$ of unfiltered incubation water were used as controls: fixation rates in these bottles were negligible and therefore no corrections were applied to fixation rates of the sediments itself. The temperature of the superficial sediments was measured at the beginning and end of the incubation period. For chlorophyll a analysis, 20 sediment samples were taken regularly distributed over a $50 \times 50 \mathrm{~m}$ quadrat with a corer (internal diameter $2.4 \mathrm{~cm}$ ) in the direct vicinity of the station. Chlorophyll a was measured (Colijn and Dijkema, 1981) according to Lorenzen's (1967) method with slight modifications: the

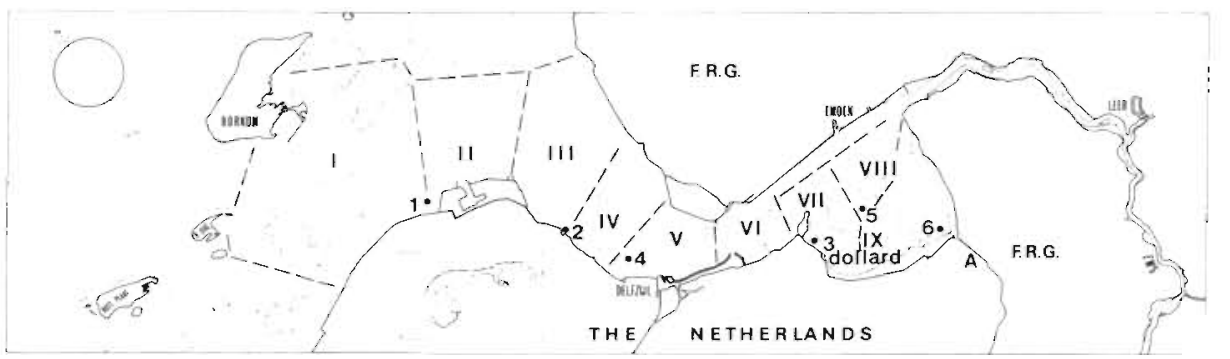

Fig. 1. Ems-Dollard estuary with location of sampling stations: $\mathrm{A}=$ Westerwoldsche $\mathrm{A}$

were situated ca. $600 \mathrm{~m}$ from a larger tidal channel (Station 2: 50 to $100 \mathrm{~m}$ ) to avoid the direct scouring influence of channel water. Stations 3, 5 and 6 were located in the Dollard, and Station 6 is in the direct vicinity of the wastewater outlet. The sediment type at each station has been described by Van Es (1982a: Table 1) and is fairly representative of the range of sediments found in the estuary. No macroalgal growth was found at the stations; however, diatoms with gelatinous tubes occasionally formed macroscopic tufts; their patchy distribution made adequate sampling difficult. All the sampling and measuring were done at low tide.

\section{Incubation techniques and sample preparation}

Benthic primary production was measured in 3 perspex cylinders (2 light and 1 dark), each $6.0 \mathrm{~cm}$ in upper $0.5 \mathrm{~cm}$ thick sediment layer was cut off and put into a centrifuge tube; all samples were deep-frozen and lyophilized to prevent inaccuracies resulting from differences in water content and to facilitate extraction; the dried sediments were extracted in 10 or $15 \mathrm{ml}$ of aqueous aceton (90\%) with the addition of magnesium carbonate, centrifuged off and the supernatants measured in a colorimeter at $664 \mathrm{~nm}$. No corrections for turbidity at $750 \mathrm{~nm}$ were made. A correction for pheopigments was made by acidification (Lorenzen, 1967). Irradiance in $\mathrm{J} \mathrm{cm}^{-2}$ was measured continuously at 10 min intervals at Delfzijl (Fig. 1) with a Kipp solarimeter (Fig. 2).

\section{Measuring ${ }^{14} \mathrm{C}$ activity}

Uptake of label was measured as follows: incubation water with a little suspended sediment was filtered 


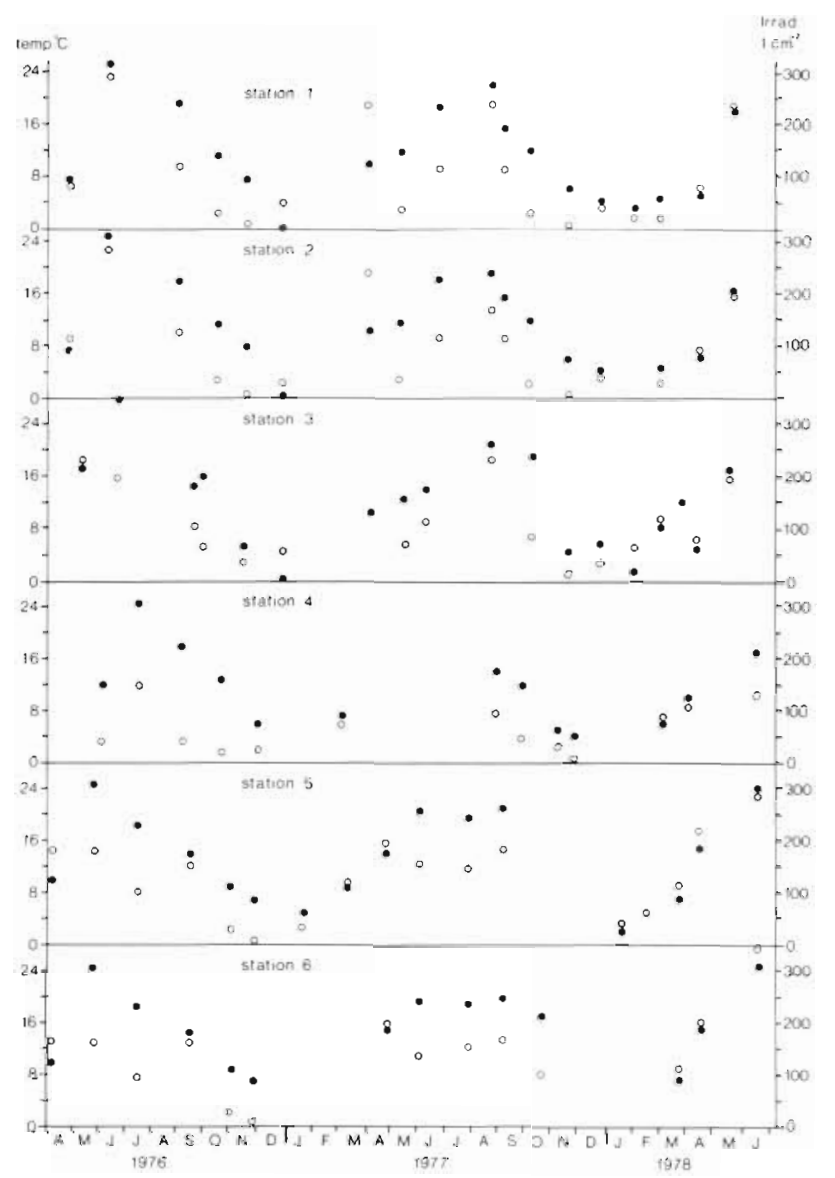

Fig. 2. Temperature (closed symbols) and irradiance $\left(\mathrm{J} \mathrm{cm}^{-2}\right.$ $\mathrm{h}^{-1}$ ) (open symbols) during field incubations

through a GF/C filter (Fraction 1). Then a layer of sediment, 0.5 to $1.0 \mathrm{~cm}$ thick, was sliced off the sediment column. Approximately a quarter of this layer was used to make a slurry which was filtered (Fraction 2) and washed with filtered seawater to remove the added inorganic ${ }^{14} \mathrm{C}$. Both fractions (1 and 2) and the remainder of the sediment were wrapped in weighted alufoils and immediately dried in a stove at $70^{\circ} \mathrm{C}$ to prevent further biological activity. Excretion rate was not measured, because other researchers (Cadée and Hegeman, 1974; Darley et al., 1976) have shown that excretion in microphytobenthos is very low (a few \% of the totally fixed carbon; see also Chapman and Rae, 1969; Hall and Fischer, 1982). To avoid problems in scintillation counting, a combustion method (Packard 306 Sample Oxidizer) was tested and used for dried sediments as well as for phytoplankton samples on filters loaded with sediment. The method was tested with labelled algae mixed with increasing amounts of sediment. In all cases the recovery of ${ }^{14} \mathrm{C}$ exceeded $95 \%$ (cf. Revsbech et al., 1981). Drying at $70^{\circ} \mathrm{C}$ did not result in loss of activity as compared with samples combusted immediately after filtration. Quench curves were made with hexadecane ${ }^{14} \mathrm{C}$ (by weight) as an internal standard, and later with the direct combustion of labelled methyl-methacrylate- ${ }^{14} \mathrm{C}$ (New England Nuclear, $35000 \mathrm{dpm}$ ) and paper strips with a ${ }^{14} \mathrm{C}$ standard which contained $5000 \mathrm{dpm}$ (Radiochemical Centre). The scintillation mixture for counting the concentration of added ${ }^{14} \mathrm{C}$ in aqueous samples was composed of BBS-3 (Beckman) $20 \%$ in toluene, and later in an Aquasol Phenethylamine mixture (5:1 v/v) (Iverson et al., 1976). The counting efficiencies were almost the same (ca. $80 \%$ ) in these 2 mixtures.

After drying and mixing well in a mortar, 3 sediment subsamples were weighed (ca. $100 \mathrm{mg}$ ) and each combusted separately in a piece of filter paper. For all calculations of the total ${ }^{14} \mathrm{C}$ uptake, the weight of the sediment fraction was used, together with the radioactivity of the two filters and in both fractions ( 1 and 2 ). All data were expressed in $\mathrm{mg} \mathrm{C} \mathrm{m}^{-2} \mathrm{~h}^{-1}$.

\section{Calculations}

Hourly fixation rates (Fig. 3B) (not corrected for dark uptake of ${ }^{14} \mathrm{C}$ ) were assumed to reflect the net assimilation rates (Williams et al., 1979). These rates were multiplied by the actual emersion period of the day on which these samples were taken, to calculate the daily production (Fig. 3A). The emersion period was determined from the actual recorded tidal curves (Rijkswaterstaat, Meet- en Adviesdienst, Delfzijl) and the elevation of each station. Five different methods were used to estimate annual production (Table 1) and to evaluate possible differences in annual production caused by different calculation methods.

Table 1. Methods for calculation of annual primary production. Effective photoperiod = emersion during daylight

Method I: Interpolation of hourly rates between measurements $x$ effective photoperiods for all days $=$ production value per day; summation of all daily values gives annual production

Method II: Hourly rate $\times$ effective photoperiod $=$ production value per measuring day; planimetry of resulting annual graph (Fig. 3A)

Method III: Hourly rate $\times$ mean annual emersion period $(\%) \times$ daylength of measuring day $=$ production value per day; planimetry of resulting annual graph

Method IV: Monthly average of hourly rates (Stations 1 to 5 and 6 ) $\times$ actual monthly effective photoperiods $=$ monthly production value; summation of monthly values

Method V: Monthly average of hourly rates (Stations 1 to 5 and 6) $\times$ calculated monthly effective photoperiod from model = monthly production value; summation of monthly values 
For these calculations average emersion periods during daylight for each station were calculated from a linear regression of the measured annual effective photoperiods against the elevation of the stations (Table 3). Annual production per station was taken as the means of the values over two successive years. Effective photoperiods in Method $\mathrm{V}$ were derived from the interaction of daylength and tidal emersion (Colijn, 1982). For all calculations given, we assumed that no irradiance reached the surface of the sediment during submersion (see 'Discussion').

\section{RESULTS}

\section{Production and chlorophyll a measurements}

Daily production values ( $\mathrm{mg} \mathrm{C} \mathrm{m}^{-2}$ ) and mean chlorophyll a data $\left(\mathrm{mg} \mathrm{m}^{-2}\right)$ are given in Fig. $3 \mathrm{~A}$, and the actual hourly rates are given in Fig. 3B. Production values per day were calculated by multiplying the hourly rate by the actual effective photoperiod on the day of measurement. Low daily values were found at all stations in winter, especially in November and December. High daily values were recorded both in spring and summer. The measurements at Station 6 were atypical: both chlorophyll $a$ and production showed comparatively high values during a large part of the year. The mean hourly rates per month showed a large month-to-month variation in these fixation rates; hourly rates were lowest in November and December, and during the rest of the year higher fixation rates were found almost irrespective of the season. However, if the data from Station 6 were omitted, the mean hourly rate was highest in April.

The fixation rates at Station 6 reached values of up to $100 \mathrm{mg} \mathrm{C} \mathrm{m}^{-2} \mathrm{~h}^{-1}$, or $1300 \mathrm{mg} \mathrm{C} \mathrm{m}^{-2} \mathrm{~d}^{-1}$. The mean hourly rate for all stations over 2 yr was ca. $37 \mathrm{mg} \mathrm{C} \mathrm{m}^{-2}$ $\mathrm{h}^{-1}$. However, this mean hourly rate was twice as high at Station 6. The mean assimilation number (production rate per unit of chlorophyll $a, \mathrm{mg} \mathrm{C} \mathrm{mg} \mathrm{chl} \mathrm{a}^{-1} \mathrm{~h}^{-1}$ ) for all measurements was 0.67 . The maximum mean value (0.49) per station was found at Station 2 , the minimum mean value $(0.43)$ at Station 6 . However, owing to the wide range in assimilation numbers per station, these mean assimilation numbers per station did not differ significantly from each other (ANOVA, $\left.F_{o}(5,89)=2,57 ; 0.05>P_{r}>0.025\right)$. Chlorophyll a concentration ranged from low winter values of $10 \mathrm{mg} \mathrm{m}^{-2}$ at Station 2 to high summer values of up to $400 \mathrm{mg} \mathrm{m}^{-2}$ at Station 6. At the other stations, values above $100 \mathrm{mg}$ $\mathrm{m}^{-2}$ were occasionally measured during short blooms. Mean values ranged from ca. $30 \mathrm{mg} \mathrm{m}^{-2}$ at Station 2 to ca. $190 \mathrm{mg} \mathrm{m}^{-2}$ at Station 6. Stations 1 to 4 showed approximately the same average value, whereas Sta- tion 5 showed a higher value, intermediate between those of Stations 1 to 4 and Station 6. A linear regres-
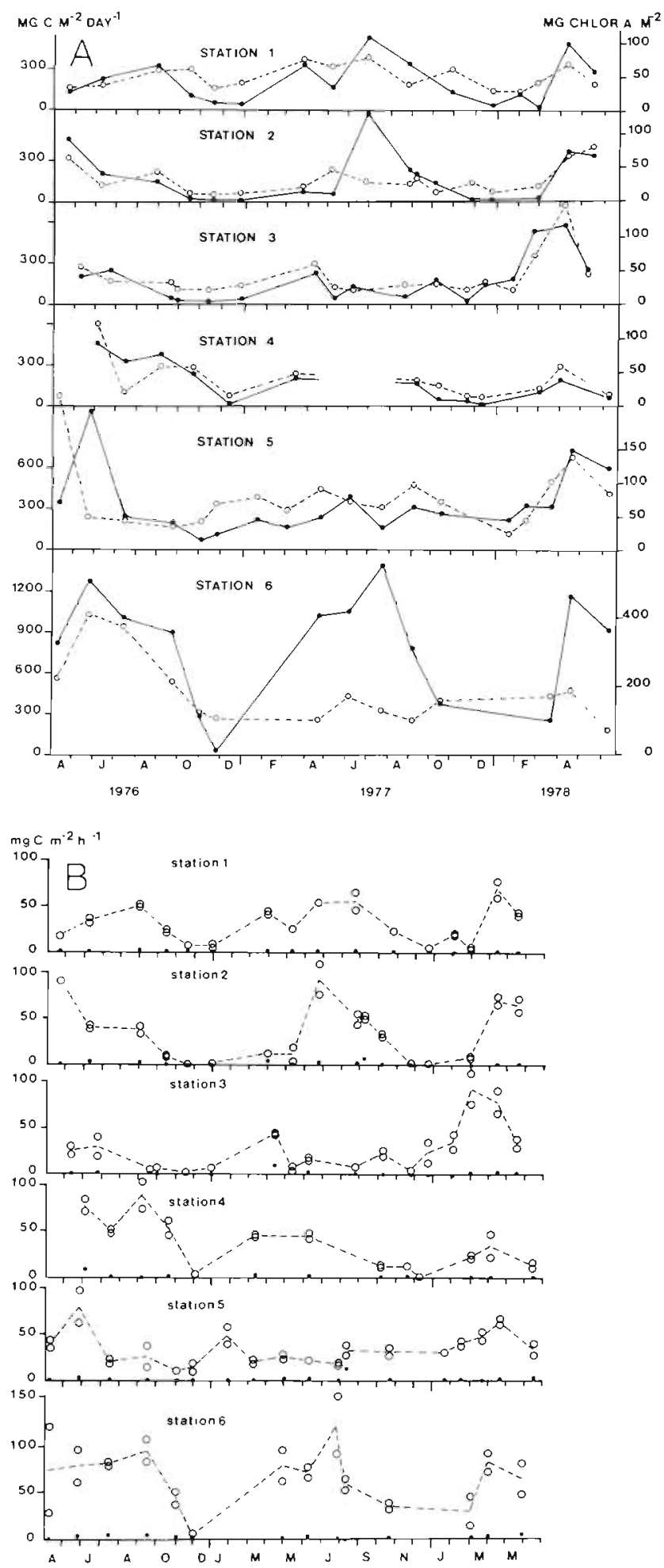

Fig. 3 (A). Daily primary production and chlorophyll $a$ at the 6 stations ( $\left.\bullet \mathrm{mg} \mathrm{C} \mathrm{m}^{-2} \mathrm{~d}^{-1} ; \circ \mathrm{mg} \mathrm{chl} a \mathrm{~m}^{-2}\right)$ (B) Primary production rates and dark uptake rates ( $\mathrm{mg} \mathrm{C} \mathrm{m}^{-2} \mathrm{~h}^{-1}$ ). Mean of light values (open symbols) are connected; dark values (small dots) 
sion of all production rates against all chlorophyll a concentrations revealed a positive correlation between these 2 variables $(x=0.5515, n=95, p<0.001$, Fig. 4).

A positive correlation was also found between these variables for each of the Stations 1 to 4 , but not for Stations 5 and 6 (Table 2). This special feature of

Table 2. Regression of primary production rate against chlorophyll a concentration in the top $0.5 \mathrm{~cm}$ of sediment, for each of the 6 stations

\begin{tabular}{|cccrcc|}
\hline Station & $N$ & Slope & Y intercept & $\mathrm{R}^{2}$ & $\mathrm{P}$ \\
\hline 1 & 16 & 0.6652 & -1.98 & 0.3351 & 0.05 \\
2 & 17 & 0.9938 & 1.26 & 0.4465 & 0.01 \\
3 & 17 & 0.6431 & -0.38 & 0.6416 & 0.01 \\
4 & 13 & 0.6871 & 7.99 & 0.5826 & 0.01 \\
5 & 18 & 0.1043 & 25.95 & 0.0811 & n.s. \\
6 & 14 & 0.0854 & 50.54 & 0.0846 & n.s. \\
$1-6$ & 95 & 0.2220 & 21.74 & 0.3042 & 0.01 \\
$1-4$ & 63 & 0.6705 & 4.01 & 0.4422 & 0.001 \\
& & & & & \\
\hline
\end{tabular}

Stations 5 and 6 is caused by the comparatively low fixation rates at high chlorophyll a concentrations (Fig. 4) which suggests that carbon fixation reached saturation values at higher chlorophyll a values.

Temperatures and irradiances measured simultaneously with the field incubations are presented in Fig. 2. Both temperature and irradiance reflected seasonal changes and showed a weak positive correlation ( $\mathrm{I}=$ 0.4487 ), which was statistically significant $(p<0.001)$. Both factors correlated positively, but weakly with the hourly production rate $(\mathrm{r}=0.3843$ and $0.3643, \mathrm{n}=95$, $\mathrm{p}<0.01$, respectively). This correlation was not significant for the data of each individual station, because of the marked variation in production rates and the paucity of observations.

Also, the assimilation number did not show a significant correlation, either with irradiance, or with temperature.

\section{Annual production}

The estimates of annual production as calculated by the 5 methods described above are presented in Table 3. Methods, I II and III gave almost identical results. Surprisingly, annual production values based on the accurately determined photoperiods (I) were almost the same as those based on the rougher Methods II and III. The results obtained by Methods IV and V were in close agreement with each other but differed from the results obtained by Methods I to III: at all stations except at Station 3, annual production on the basis of mean monthly production values $\mathrm{mg} \mathrm{C}^{-2} \mathrm{~h}^{-1}$ ) was lower than on the basis of actually measured production values. The differences in annual production val-
Table 3. Annual primary production in $\mathrm{g} \mathrm{C} \mathrm{m}^{-2}$ at 5 stations in the Ems-Dollard Estuary as based on 1 set of data and 5 different methods of calculation ('Material and Methods'), together with the mean chlorophyll a concentration and the mean emersion period (as \% of tidal cycle) of each station. All annual production values are exclusively based on the emersion periods of the stations. NAP $=$ approx. mean sea level

\begin{tabular}{|cccccrr|}
\hline \multirow{2}{*}{ Method } & \multicolumn{7}{c|}{$\begin{array}{c}\text { Station } \\
\end{array}$} & 1 & 2 & 3 & 4 & 5 & 6 \\
\hline I & 81 & 62 & 62 & 62 & 99 & 245 \\
II & 77 & 56 & 59 & 61 & 106 & 256 \\
III & 76 & 57 & 67 & 58 & 101 & 245 \\
IV & 73 & 57 & 82 & 53 & 99 & 200 \\
V & 70 & 54 & 84 & 51 & 98 & 214 \\
Mean chlorophyll & 49 & 33 & 42 & 40 & 77 & 184 \\
$\begin{array}{l}\text { a (mg m-2) } \\
\text { Station elevation } \\
\text { (m NAP) }\end{array}$ & 0 & -.4 & +.3 & -.5 & +.7 & +1.1 \\
Average annual & 49 & 37 & 57 & 35 & 69 & 80 \\
$\begin{array}{c}\text { emersion (\%) } \\
\text { during daylight }\end{array}$ & & & & & & \\
\hline
\end{tabular}

ues calculated by Methods IV and V are completely determined by the elevation of the stations and the tidal range, in other words, by the effective photoperiod. The percentual agreement between the results obtained by Methods IV and V proves that the calculation of the effective photoperiods with the model is in accord with actually measured photoperiods (Table 3 , Methods IV and V).

The linear extrapolation of the tidal emersion effect (Table 3 , Methods IV to $\mathrm{V}$ ) would result in an expected production of ca. $110 \mathrm{~g} \mathrm{C} \mathrm{m}^{-2} \mathrm{yr}^{-1}$ at Station 6 . The actual value was roughly twice as high, because of the much higher production rate at this station, notwithstanding the relatively low mean assimilation number. The atypicality of this station in the estuary is also reflected by the very high chlorophyll a values (Fig. 3A).

Dark ${ }^{14} \mathrm{C}$ fixation values (Fig. 3B) showed no correlation with production rate, temperature, or station number. The mean value was $2.09 \mathrm{mg} \mathrm{C} \mathrm{m}^{-2} \mathrm{~h}^{-1}$, which is $5.6 \%$ of the mean hourly production rate. As pointed out under Material and methods we assumed that primary production only occurred during emersion. Obviously, this holds for the turbid inner part of the estuary, but not for the outer part with much clearer waters. Therefore, we calculated, using the characteristic values of Station 1, the effective light period which is defined now as the emersion period plus the submersion time, when photosynthetic active radiation (PAR) at the sediment surface exceeded $25 \mathrm{~W} \mathrm{~m}^{-2}$. This value is assumed to equal the saturation irradiance (Colijn and Van Buurt, 1975). With these assumptions the total effective light period increases by $25 \%$. For 
Station 1 this would increase the annual primary production from 70 to $89 \mathrm{~g} \mathrm{C} \mathrm{m}^{-2}$ (Method V). Although we had no measurements during submersion to check this estimate, it seems to be realistic (cf. Cadée and Hegeman, 1974).

\section{DISCUSSION}

\section{Methodology}

The problem of self-absorption normally encountered when one determines radiocarbon in sediment samples can be solved in several ways. In liquid scintillation counting, high counting efficiences are easily obtained by suspending the sediment in a gelling scintillation cocktail (Skauen et al., 1971; Cadée and Hegeman, 1974, 1977). However, only small amounts of sediment can be subjected to this procedure, especially as the sediment contains silt with high quenching properties. The acid digestion method (Van Raalte et al., 1974) has proved to be unsuccessful, because of an unexplained low recovery. The combustion method which we adopted lacks the above disadvantages. Thus we could process samples of up to a few $100 \mathrm{mg}$ of dry sediment with almost $100 \%$ recovery and reach counting efficiencies of ca. $75 \%$. However, the nonuniform distribution of the labelled incubation solution in the upper sediment layer is a problem (cf. Colijn and Van Buurt, 1975). Also, the concentrations of inorganic carbon in the upper sediment layers may differ from the concentration in the incubation water (Klein, 1981; Revsbech et al., 1981; Lindeboom and De Bree, 1982). A few measurements of the concentration of total inorganic carbon showed (unpubl. own results) that the surface water film and the 0 to $2 \mathrm{~mm}$ deep layer had minor differences in inorganic carbon content (cf. Revsbech et al., 1981). Because we did not measure the specific activity of $\mathrm{H}^{14} \mathrm{CO}_{3}^{-}$in the upper sediment layers, there is some uncertainty about the actual fixation rates in these layers. According to Revsbech et al., (1981) this may cause an underestimation of the fixation rate in deeper layers up to a factor of 2 to 5 . The very small light penetration in our sediments (Colijn, 1982) may well reduce this error, because the maximal photosynthetic rates take place within a layer of only $0.5 \mathrm{~mm}$ (Revsbech and Jorgensen, 1983). An advantage of the in situ method is that the sediment with the microalgal layer stays intact and that the flux of nutrients including bicarbonate from the deeper sediment layers is not disrupted. Measurements of nutrient concentrations in channel waters in the Dollard have shown that these nutrient concentrations usually are high (de Jonge and Postma, 1974; Rutgers van der Loeff et al., 1981), Nutrient limitation is not necessarily occurring in the thin film of water overlying the mud- flat since nutrient uptake and photosynthesis are not always coupled (Eppley, 1981). We think that, generally, nutrients will not act as a limiting factor for the growth of the microphytobenthic vegetation in the Ems-Dollard estuary (cf. Admiraal et al., 1982).

In our investigation, the sample surface (ca. $28 \mathrm{~cm}^{2}$ ) was large enough to prevent 'edge effects' from playing an important role, as can easily occur with very small samples (Marshall et al., 1973; cf. Cadée and Hegeman, 1974). The water flow, which is an inevitable consequence of the bell-jar technique (Van Es, 1982a), creates a major problem. Generally, stirring stimulates both macroalgae and sediment-inhabiting microalgae to give higher production values (UNESCO manual, 1973; Boynton et al., 1981; Revsbech et al., 1981), possibly by improving $\mathrm{CO}_{2}$ exchange (Admiraal et al., 1982), or by removing inhibiting $\mathrm{O}_{2}$, or by suspending algae and thereby increasing their average illumination. An increase in production, however, is not always found (Hargrave et al., 1983). In our view, microphytobenthos on intertidal flats is not subjected to any appreciable water flow during emersion, and therefore the best imitation of the natural emerged environment should be a non-stirred incubator. Not even such a non-stirred incubator fully reproduces conditions on a natural emerged sand- or mudflat (Darley et al., 1976). However, Darley et al. found that during $1 \mathrm{~h}$ experiments air-incubated samples showed a linear uptake of label at a rate comparable with that shown by submerged samples. A recent study (Holmes and Mahall, 1982) revealed that flooding with a 1 to 2 $\mathrm{mm}$ layer of agitated water reduced net photosynthetic rates by ca. $50 \%$. Although the cause of this reduction was not given, it is reasonable to infer that the reduction was the result of the microalgae migrating into deeper layers. During our measurements we never observed a visual downwards migration of diatoms.

\section{Production rate, algal biomass and environmental factors}

Possible relationships between primary production and environmental factors can be established by applying stepwise multiple regression analysis (Van Es, 1982a). This analysis showed that only chlorophyll $a$ values explained the variation in production values for all station, but other factors (temperature und irradiance) made a very inconsistent contribution to the variance. Although the main goal of our study was to establish the annual primary production in the EmsDollard estuary (with an area of ca. $500 \mathrm{~km}^{2}$ ), knowledge on the factors regulating this production is also important. The significant positive correlation between algal biomass (expressed as $\mathrm{mg} \mathrm{chl} \mathrm{a} \mathrm{m}^{-2}$ ) and 
the production rate (Colijn and Venekamp, 1977; Plante-Cuny, 1978) should enable us to make rough estimates of the primary production over greater areas without time consuming production measurements. A statistically significant correlation was found between mean annual production (Method I) and mean chlorophyll a concentration over the same period ( $\mathrm{r}=0.9973, \mathrm{n}=6, \mathrm{p}<0.001$; without Station 6: $\mathrm{r}=0.9689, \mathrm{n}=5, \mathrm{p}<0.01$ ) (Table 2, Fig. 5).

A similar, close correlation between mean annual chlorophyll a content and annual production was found by Cadée and Hegeman (1977) in the Western

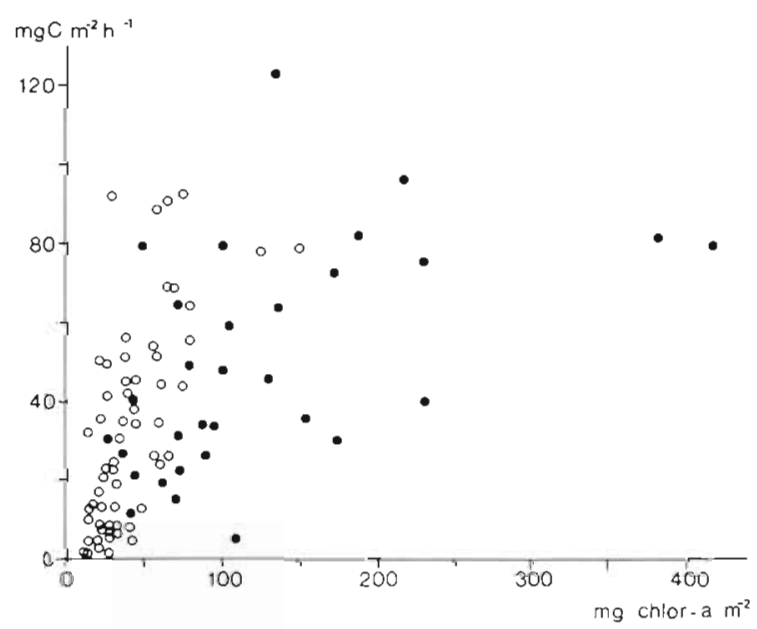

Fig. 4. Relation between chlorophyll a concentration and production rate. Open symbols: Stations 1 to 4; closed symbols. Stations 5 and 6

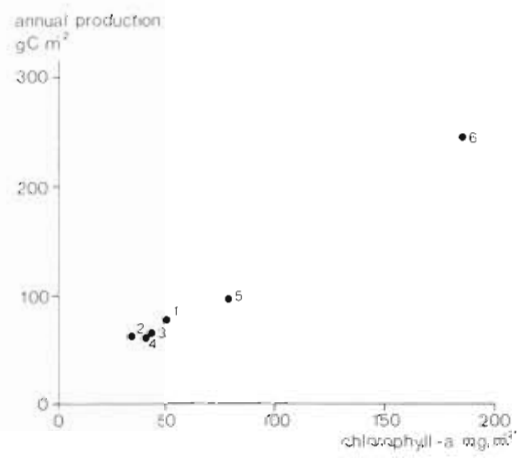

Fig. 5. Relation between annual mean chlorophyll a concentration and annual primary production for the 6 stations studied

Wadden Sea. However, the slope of their regression line is less steep than ours; the reason for this difference is that their chlorophyll a measurements included sediment to a depth of $1 \mathrm{~cm}$, while ours included sediment only to a depth of $0.5 \mathrm{~cm}$. Thus, we agree with Cadée und Hegeman, that the annual microphytobenthic production can be estimated on the basis of relatively few chlorophyll a samples distributed over the year. On the other hand, this method yields only a limited insight into the year-round variability of the primary-produced organic carbon available for estuarine processes of grazing, burial, transport and mortality. Daily production rates and chlorophyll a concentrations were expected to increase with increasing elevation of the stations. However, biomass only increased in this way at Stations 5 and 6 , and production rates were only relatively high at Station 6. A significant positive correlation between primary production and tidal level was also found by Cadée and Hegeman (1977), and we agree that this is caused by the longer effective photoperiods on the more elevated tidal flats. This is supported by Admiraal (1977a) who investigated the minimum irradiance requirement of benthic diatoms in culture. Extrapolation of these and other literature data (Colijn, 1982) shows that a minimum irradiance for saturating diatom growth occurs during most of the year; only during winter may irradiance be limiting (Colijn and Dijkema, 1981; Colijn, 1982) through the combination of low solar irradiance and short effective photoperiods. Field observations (Admiraal and Peletier, 1980) have also shown that the starting point in spring of the growth of natural diatom vegetations on a short transect with 3 stations at different tidal levels correlated with the duration of emersion; the higher stations exhibited an earlier start than the lower stations. The high primary production rate at Station 6 largely resulted from that station's high elevation. The high chlorophyll a concentration accorded with the high primary production. As mentioned before, the influence of elevation alone could not account for the high production level; other factors may have enhanced this production: the sheltered position of Station 6, the lack of macrofaunal grazers (Van Es et al., 1980), the high nutrient concentration in the tidal water and in the pore water (De Jonge, unpubl.), combined with the high mineralization rate of allochthonic organic material (Van Es, 1982b) that supplies inorganic carbon. The population of benthic algae mostly consisted of diatoms, but it also contained blue-green algae and Euglenophyceae, particularly in summer. This vegetation had a lower specific production rate than the diatom vegetations of the other stations. However, interpreting the assimilation numbers raises problems, the depth of the photic layer in the sediment strongly depends on the composition of the sediment (Colijn, 1982). When the specific production rates were calculated from the chlorophyll a contents of the top $0.5 \mathrm{~cm}$ of sediment, it was assumed that all chlorophyll in this layer contributes to the primary production, because it was impossible to measure chlorophyll $a$ in the photic layer properly. Consequently, the assimilation number was always underestimated. The absence of a significant correla- 
tion between primary production rate and temperature or irradiance was surprising at first sight. Laboratory experiments with small cores (Colijn and van Buurt, 1975) have shown that both temperature and irradiance enhance the primary production rate unless irradiance reaches saturation levels. That no correlation between irradiance and photosynthetic rate, and assimilation number was found can be explained by the incubation irradiances, which nearly always exceeded a saturation level of $11-25 \mathrm{~W} \mathrm{~m} \mathrm{~m}^{-2}$ (PAR) (recalculated from Colijn and van Buurt, 1975). Our field incubations in November, December, January and February were performed with lower irradiance values only.

The lack of correlation between production rate and assimilation number with temperature contrasts with results obtained by Admiraal and Peletier (1980). They observed that doubling rates of cultures in enclosed incubators increased from ca. $0.2 \mathrm{~d}^{-1}$ in winter to more than $2 \mathrm{~d}^{-1}$ in late spring. However, simultaneously observed doubling rates of natural populations were always much lower (max. $0.1 \mathrm{~d}^{-1}$ ) even under high $\left(>20^{\circ} \mathrm{C}\right.$ ) temperatures. Apparently, in our field incubations the effect of temperature on production rate is obscured by other factors. The observed low doubling rates (Admiraal and Peletier, 1980) and the relatively low chlorophyll a concentrations at Stations 1 to 4 are probably caused by grazing, burying and transport. In other studies, the removal of epibenthic grazers resulted in a significant increase in algal biomass and productivity (Pace et al., 1979; Darley et al., 1981). These results, however, are not in accordance with those obtained by Connor et al. (1982), who observed a positive feedback between grazing by mud snails and the chlorophyll standing stock, at least at low animals densities. If the microcosms were raked daily and densities of snails were high, the algal biomass and rates of photosynthesis fell. Also the removal of a proportion of the actively growing diatoms from the photic zone into the aphotic sediment layers (De Jonge and Colijn, in prep.) and suspension and transport by tidal currents (Cadée and Hegemann, 1974; Ballie and Welsh, 1980; de Jonge, 1983) can keep the benthic diatom population at a low level

High primary production and chlorophyll a concentrations at Station 6 probably form the limit for microphytobenthic vegetations. This limit can be set by high concentrations of $\mathrm{O}_{2}$, low diffusion flux of $\mathrm{CO}_{2}$ into the microalgal layer (Admiraal et al., 1982) and absorption of PAR by chlorophyll a and fine sediment particles (Fenchel and Staarup, 1971; Colijn, 1982). This hypothesis is supported by the saturation of production rate (Fig. 4) and by the low assimilation numbers at very high chlorophyll concentrations at Station 6 during favourable conditions of temperature and irradiance: 0.19 and $0.20 \mathrm{mg} \mathrm{C} \mathrm{mg} \mathrm{chl} \mathrm{a}^{-1} \mathrm{~h}^{-1}$ were measured at Station 6 on 25. V. and 14. VII. 1976 , respectively, as opposed to a mean value of 1.37 for 8 other measurements at temperatures above $19{ }^{\circ} \mathrm{C}$, irradiance $>150 \mathrm{~W} \mathrm{~m}^{-2}$, and chlorophyll a concentrations below $50 \mathrm{mg} \mathrm{m}^{-2}$.

Recently, Admiraal et al. (1983) have discussed 2 different interpretations of the term primary production; the first was based on the photosynthetic rate on an hourly basis, as in this study, the second on the biomass increase over $24 \mathrm{~h}$ periods. They showed that in the latter case at a biomass density of $4 \mathrm{~g} \mathrm{C} \mathrm{m}^{-2}$ (roughly equivalent to $100 \mathrm{mg} \mathrm{chl} \mathrm{a} \mathrm{m}^{-2}$ ) biomass net production might be as low as zero. That we were still able to measure positive fixation rates reflects the inherent property of the ${ }^{14} \mathrm{C}$ method that neither excretion nor respiration rates are subtracted from the fixation rates on a $24 \mathrm{~h}$ basis. Thus it is still not clear how much fixed carbon is available for primary consumers per year.

\section{Comparison with other areas}

Data on primary production form intertidal flats and shallow coastal areas around the world have been compiled in Table 4. Two important results are obvious from this table: Firstly, the annual production data measured with a bell-jar technique in the Ems-Dollard estuary and partly during the same period (Van Es, 1982a) fit in with ${ }^{14} \mathrm{C}$ fixation rates: $r=0.9699, \mathrm{n}=6$, $p<0.01$, (slope $=1.27$ ). Thus both techniques give roughly identical estimates of annual primary production (Hunding and Hargrave, 1973). However, the individual, actually measured hourly rates per station showed large variations, probably because the measurements could not be performed at exactly the same spot; patchy distribution of microalgae (Van den Hoek et al., 1979) can lead to a 2- to 10-fold difference in chlorophyll a concentration and cell numbers over a distance of a few centimetres (De Jonge and Colijn, in prep.). Secondly, the values for annual primary production at stations in the Western Wadden Sea (Cadée and Hegeman, 1974, 1977) are in the same range as the data from our Stations 1 to 5, again with the exception of our Station 6, with higher values than those of their Station 1 (188 $\mathrm{g} \mathrm{C} \mathrm{m}^{-2} \mathrm{yr}^{-1}$ ). Leach (1970) showed that with relatively high chlorophyll a values (400 to 600 $\mathrm{mg} \mathrm{m}^{-2}$ ) the annual production was rather low $(31 \mathrm{~g} \mathrm{C}$ $\mathrm{m}^{-2} \mathrm{yr}^{-1}$ ). This might be caused by the muddy sediments (Station 3) with a thin photic layer and a high chlorophyll a content in the deeper sediment layers. Surprisingly, as Table 4 shows, on a more global scale most of the annual production values are within a narrow range from 50 to $200 \mathrm{~g} \mathrm{C} \mathrm{m}^{-2}$, even though they were determined at very different geographical 
Table 4. Comparison of annual production rates in intertidal and shallow coastal sediments. Upper part: ${ }^{14} \mathrm{C}$-values; lower part: $\mathrm{O}_{2}$-values

\begin{tabular}{|c|c|c|c|c|c|c|c|}
\hline Locality (Lat.) & $\begin{array}{l}\text { Sediment typ, } \\
\text { depth }(m)\end{array}$ & Method & $\begin{array}{l}\text { Annual } \\
\text { production } \\
\left(\mathrm{g} \subset \mathrm{m}^{-2}\right)\end{array}$ & $\begin{array}{l}\text { Production rate } \\
\left(\mathrm{mg} \mathrm{C}^{-2} \mathrm{~h}^{-1}\right) \\
\text { range } \text { mean }^{-1}\end{array}$ & $\begin{array}{l}\text { Chlorophyll } \\
\left(\mathrm{mg} \mathrm{m}^{-2}\right)\end{array}$ & $\begin{array}{l}\text { Dominating } \\
\text { microphytes }\end{array}$ & References \\
\hline $\begin{array}{l}\text { Danish fjords } \\
\left(55^{\circ} \mathrm{N}\right)\end{array}$ & $\begin{array}{l}\text { Littoral sand } \\
\& \text { mud, } 0.2-1.8 \mathrm{~m}\end{array}$ & ${ }^{14} \mathrm{C}$ & 116 & $25-90 ; 60$ & n.d. & Pennate diatoms & Grontved (1960) \\
\hline $\begin{array}{l}\text { Danish Wadden } \\
\text { Sea }\left(55^{\circ} \mathrm{N}\right)\end{array}$ & $\begin{array}{l}\text { Intertidal } \\
\text { sands }\end{array}$ & ${ }^{14} \mathrm{C}$ & $\begin{array}{l}571 \\
\text { (sheltered) } \\
892 \\
\text { (exposed) }\end{array}$ & $\begin{array}{l}25-300 \\
25-500\end{array}$ & n.d. & Pennate diatoms & Grentved (1962) \\
\hline $\begin{array}{l}\text { Loch Ewe, } \\
\text { Scotland } \\
\left(57^{\circ} 50^{\prime} \mathrm{N}\right)\end{array}$ & Sandy beach & ${ }^{14} \mathrm{C}$ & $4-9$ & $\begin{array}{l}0.14-1.78 \mathrm{mg} \mathrm{C} \\
\mathrm{mg} \mathrm{Chl} \mathrm{C}^{-1} \mathrm{~h}^{-1}\end{array}$ & $\begin{array}{l}3-20 \mu \mathrm{g} \mathrm{g}^{-1} \\
\text { dry sediment }\end{array}$ & $\begin{array}{l}\text { Sand-attached } \\
\text { diatoms }\end{array}$ & $\begin{array}{l}\text { Steele and Baird } \\
\text { (1968) }\end{array}$ \\
\hline $\begin{array}{l}\text { Ythan estuary, } \\
\text { Scotland } \\
\left(57^{\circ} \mathrm{N}\right)\end{array}$ & $\begin{array}{l}\text { Intertidal } \\
\text { muds }\end{array}$ & ${ }^{14} \mathrm{C}$ & 31 & $4-26 ; 10$ & $\begin{array}{l}25-34 \mu \mathrm{g} \mathrm{g}^{-1} \\
\text { dry sediment }\end{array}$ & $\begin{array}{l}\text { Motile pennate } \\
\text { diatoms }\end{array}$ & Leach (1970) \\
\hline $\begin{array}{l}\text { South New } \\
\text { England, USA } \\
\left(41^{\circ} \mathrm{N}\right)\end{array}$ & $\begin{array}{l}\text { Intertidal } \\
\text { mixed sediment }\end{array}$ & ${ }^{14} \mathrm{C}$ & 81 & $8.2-30.8 ; 20.1$ & 100 & $\begin{array}{l}\text { Pennate diatoms } \\
\text { dinoflag., fila- } \\
\text { mentous algae }\end{array}$ & $\begin{array}{l}\text { Marshall et al. } \\
\text { (1971) }\end{array}$ \\
\hline $\begin{array}{l}\text { Niva Bay, } \\
\text { Øresund, } \\
\text { Denmark }\left(56^{\circ} \mathrm{N}\right)\end{array}$ & $\begin{array}{l}\text { Shallow sands, } \\
0.5 \mathrm{~m}\end{array}$ & ${ }^{14} \mathrm{C}$ & n.d. & $125-300^{\circ}$ & n.d. & $\begin{array}{l}\text { Free-living and } \\
\text { attached diatoms }\end{array}$ & Gargas $(1970)$ \\
\hline $\begin{array}{l}\text { Madagascar } \\
\left(13^{\circ} \mathrm{S}\right)\end{array}$ & $\begin{array}{l}\text { Marine sands, } \\
5-60 \mathrm{~m}\end{array}$ & ${ }^{14} \mathrm{C}$ & $\begin{array}{l}150(5 \mathrm{~m}) \\
66(\text { mean) }\end{array}$ & 9.22 & 38,78 & $\begin{array}{l}\text { Cyanophyceae, } \\
\text { diatoms, symbio- } \\
\text { tic dinoflag }\end{array}$ & $\begin{array}{l}\text { Plante-Cuny } \\
\text { (1978) }\end{array}$ \\
\hline $\begin{array}{l}\text { Madagascar } \\
\left(13^{\circ} \mathrm{S}\right)\end{array}$ & $\begin{array}{l}\text { Marine sands, } \\
5-38 \mathrm{~m}\end{array}$ & ${ }^{14} \mathrm{C}$ & n.d. & 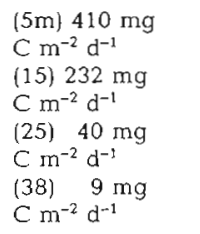 & $3-34$ & Ditto & $\begin{array}{l}\text { Plante-Cuny } \\
\text { (1973) }\end{array}$ \\
\hline $\begin{array}{l}\text { Mediterranean } \\
\text { coast, France } \\
\left(43^{\circ} \mathrm{N}\right)\end{array}$ & $\begin{array}{l}\text { Marine sands, } \\
\text { up to } 12 \mathrm{~m}\end{array}$ & ${ }^{14} \mathrm{C}$ & n.d. & $\begin{array}{l}120-194 \mathrm{mg} \\
C \mathrm{~m}^{-2} \mathrm{~d}^{-1}\end{array}$ & $24-64$ & n.d. & $\begin{array}{l}\text { Colocoloff } \\
(1972)\end{array}$ \\
\hline $\begin{array}{l}\text { Falmouth Bay, } \\
\text { USA }\left(41^{\circ} \mathrm{N}\right)\end{array}$ & $\begin{array}{l}\text { Salt marsh } \\
\text { muds }\end{array}$ & ${ }^{14} \mathrm{C}$ & $105.5 \pm 12.5$ & $5-80$ & n.d. & n.d. & $\begin{array}{l}\text { van Raalte et al. } \\
(1976)\end{array}$ \\
\hline $\begin{array}{l}\text { Chuchi Sea, } \\
\text { USA }\left(71^{\circ} N\right)\end{array}$ & $\begin{array}{l}\text { Fine muds and } \\
\text { sands } 5 \mathrm{~m}\end{array}$ & ${ }^{14} \mathrm{C}$ & 5 & $0.5-57$ & $40-320$ & $\begin{array}{l}\text { Diatoms and } \\
\text { Euglenophyceae }\end{array}$ & $\begin{array}{l}\text { Matheke and } \\
\text { Horner (1974) }\end{array}$ \\
\hline $\begin{array}{l}\text { Wadden Sea, } \\
\text { Netherlands } \\
\left(53^{\circ} \mathrm{N}\right)\end{array}$ & $\begin{array}{l}\text { Intertidal flats } \\
\text { (sandy-mud) }\end{array}$ & ${ }^{14} \mathrm{C}$ & $100 \pm 40$ & $\begin{array}{l}50-100 \text { (winter) } \\
100-1100 \\
\text { (summer) }\end{array}$ & $\begin{array}{l}7.1 \mu \mathrm{g}^{-1} \\
\text { dry sediment } \\
100 ; 40-400\end{array}$ & $\begin{array}{l}\text { Attached and } \\
\text { suspendable } \\
\text { diatoms }\end{array}$ & $\begin{array}{l}\text { Cadée and } \\
\text { Hegeman (1974) }\end{array}$ \\
\hline $\begin{array}{l}\text { River Lynher } \\
\text { estuary, } \mathrm{SW} \\
\text { England }\left(50^{\circ} \mathrm{N}\right)\end{array}$ & $\begin{array}{l}\text { Intertidal } \\
\text { mudflats }\end{array}$ & ${ }^{14} \mathrm{C}$ & 143 & $5-115$ & $\begin{array}{l}30-80 \mu \mathrm{g} \mathrm{g}^{-1} \\
\text { dry sediment }\end{array}$ & n.d. & Joint (1978) \\
\hline $\begin{array}{l}\text { Balgzand, } \\
\text { Wadden Sea } \\
\left(53^{\circ} \mathrm{N}\right)\end{array}$ & $\begin{array}{l}\text { Intertidal } \\
\text { flats, } \\
4 \text { transects }\end{array}$ & ${ }^{14} \mathrm{C}$ & $\begin{array}{l}85(29-188) \\
\text { (15 stations) }\end{array}$ & $0-900\left(d^{-1}\right)$ & $\begin{array}{l}3-13 \mu \mathrm{g} \mathrm{g}^{-1} \\
\text { dry sediment }\end{array}$ & Diatoms & $\begin{array}{l}\text { Cadée and } \\
\text { Hegeman (1977) }\end{array}$ \\
\hline $\begin{array}{l}\text { Bolsa, Bay, } \\
\text { USA }\left(34^{\circ} \mathrm{N}\right)\end{array}$ & $\begin{array}{l}\text { Barren estua- } \\
\text { rine mudflats }\end{array}$ & ${ }^{14} \mathrm{C}$ & $115-246$ & $\begin{array}{l}26-59 \\
\text { (4 stations) }\end{array}$ & $\begin{array}{l}185-385 \\
\text { (annual mean) }\end{array}$ & $\begin{array}{l}\text { Motile \& non- } \\
\text { motile diatoms, } \\
\text { bluegreens, } \\
\text { dinoflagellates }\end{array}$ & $\begin{array}{l}\text { Riznyk et al. } \\
(1978)\end{array}$ \\
\hline $\begin{array}{l}\text { Ems-Dollard } \\
\text { estuary } \\
\left(53^{\circ} \mathrm{N}\right)\end{array}$ & $\begin{array}{l}\text { Intertidal } \\
\text { mudflats }\end{array}$ & ${ }^{14} \mathrm{C}$ & $\begin{array}{l}62-276 \\
\text { (6 stations) }\end{array}$ & $1-120 ; 37.0$ & $\begin{array}{l}33-184 \\
\text { (annual mean) }\end{array}$ & $\begin{array}{l}\text { Diatoms, occ. } \\
\text { Euglenophyceae } \\
\text { bluegreens }\end{array}$ & This study \\
\hline $\begin{array}{l}\text { Ems-Dollard } \\
\text { estuary } \\
\left(53^{\circ} \mathrm{N}\right)\end{array}$ & $\begin{array}{l}\text { Intertidal } \\
\text { mudflats }\end{array}$ & $\mathrm{O}_{2}$ & $\begin{array}{l}69-314 \\
\text { (6 stations) }\end{array}$ & $\begin{array}{l}0-1900 \mathrm{mg} \mathrm{C} \\
\mathrm{m}^{-2} \mathrm{~d}^{-1}\end{array}$ & n.d. & $\begin{array}{l}\text { Diatoms, occ. } \\
\text { Euglenophyceae } \\
\text { bluegreens }\end{array}$ & van Es (1982a) \\
\hline $\begin{array}{l}\text { False Bay, } \\
\text { USA }\left(48^{\circ} \mathrm{N}\right)\end{array}$ & $\begin{array}{l}\text { Intertidal } \\
\text { sandflats }\end{array}$ & $\mathrm{O}_{2}$ & $\begin{array}{l}143-226 \\
\text { (3 stations) }\end{array}$ & $0-100$ & $\begin{array}{l}30-70 \mu \mathrm{g}^{-1} \\
\text { dry sediment }\end{array}$ & $\begin{array}{l}\text { Diatoms } \\
\text { (Navicula spp.) }\end{array}$ & Pamatmat (1968) \\
\hline $\begin{array}{l}\text { Georgia salt } \\
\text { marshes, USA } \\
\left(31^{\circ} \mathrm{N}\right)\end{array}$ & $\begin{array}{l}\text { Intertidal } \\
\text { mudflats }\end{array}$ & $\mathrm{O}_{2}$ & 200 & $5-140$ & n.d. & $\begin{array}{l}\text { Pennate diatoms } \\
\text { flagellates, } \\
\text { bluegreens, } \\
\text { dinoflagel. }\end{array}$ & Pomeroy (1959) \\
\hline $\begin{array}{l}\text { Bay of Fundy, } \\
\text { Canada }\left(45^{\circ} \mathrm{N}\right)\end{array}$ & $\begin{array}{l}\text { Intertidal } \\
\text { flats }\end{array}$ & $\mathrm{O}_{2}$ & $47-83$ & $10-800$ & $10-500$ & Microalgae & $\begin{array}{l}\text { Hargrave et al. } \\
\text { (1983) }\end{array}$ \\
\hline
\end{tabular}


latitudes. An exception are the data obtained by Steele and Baird (1968) who found a very low annual production, probably a result of the washout of free-living diatoms from their wave-exposed sands and the dispersal of viable cells to at least $20 \mathrm{~cm}$ depth. Other very low values have been found in polar regions and can be ascribed to the short growing season (Matheke and Horner, 1974). The high values given by Grontved (1962) are based on potential measurements and do not reflect in situ production conditions.

As pointed out also by Cadée and Hegeman (1974), the spreading of small sediment cores results in much higher primary production. There is a possible explanation for the small range of annual production values. The abiotic environment in tidal areas largely precludes the existence of stable, permanent microalgal vegetations, because the cells are continually being suspended and removed. Moreover, the photic layer in sediments is too thin to enable all availabe cells to contribute optimally to the process of primary production. Thirdly, if an algal layer is formed, its growth is reduced through its own photosynthesis products or because the diffusion of carbon dioxide and nutrients is hampered in the algal film. All these processes limit the formation of a considerable microalgal biomass and restrict the concomitant net primary production.

Acknowledgements. The authors express their special thanks to Loes Venekamp for technical assistance. We also like to thank Professor Dr. C. van den Hoek, as well as Drs. W Admiraal, G. C. Cadée and P. de Wolf for critically reading the manuscript and for many suggestions. Mrs. J. Burrough Boenish improved the English.

\section{LITERATURE CITED}

Admiraal, W. (1977a). Influence of light and temperature on the growth rate of estuarine benthic diatoms in culture. Mar. Biol. 39: 1-9

Admiraal, W. A. (1977b). Influence of various concentrations of orthophosphate on the division rate of an estuarine benthic diatom, Navicula arenaria, in culture. Mar. Biol. 42: $1-8$

Admiraal, W A. $(1977 \mathrm{c})$. Salinity tolerance of benthic estuarine diatoms as tested with a rapid polarographic measurement of photosynthesis. Mar Biol. 39: 11-18

Admiraal, W. A. (1980). Experiments on the ecology of benthic diatoms in the Eems-Dollard estuary. Biologisch Onderzoek Eems-Dollard Estuarium, Publikaties en Verslagen 1980-3: 1-125

Admiraal, W., Peletier, H. (1980). Influence of seasonal variations of temperature and light on the growth rate of culture and natural populations of intertidal diatoms. Mar. Ecol. Prog. Ser. 2: 35-43

Admiraal, W., Peletier, H., Zomer, H. (1982). Observations and experiments on the population dynamics of epipelic diatoms from an estuarine mudflat. Estuar. coast. Shelf Sci. 14: $471-487$
Admiraal, W. A., Bouwman, L. A., Hoekstra, L., Romeyn, K. (1983). Qualitative and quantitative interactions between microphytobenthos and herbivorous meiofauna on a brackish intertidal mudflat. Int. Revue ges. Hydrobiol. 68: $175-191$

Ballie, P. W., Welsh, B. L., 1980. The effect of tidal resuspension on the distribution of intertidal epipelic algae in an estuary. Estuar. coast. mar Sci. 10 (2): 165-180

Boynton, W. R., Osborne, W. M., Osborne, C. G. Kanmeyer, K. R., Jenkins, M. C. (1981). Influence of water circulation rate on in situ measurements of benthic community respiration. Mar. Biol. 65 (2): 185-190

Cadée, G. C., Hegeman, J. (1974). Primary production of the benthic microflora living on tidal flats in the Dutch Wadden Sea. Neth. J. Sea. Res. 8 (2/3): 260-291

Cadée, G. C., Hegeman, J. (1977). Distribution of primary production of the benthic microflora and accumulation of organic matter on a tidal flat area, Balgzand, Dutch Wadden Sea. Neth. J. Sea Res. 11 (1): 24-41

Chapman, G., Rae, A. C. (1969). Excretion of photosynthate by a benthic diatom. Mar. Biol. 3: 341-351

Colijn, F. (1978). Primary productivity measurements in the Ems-Dollard Estuary during 1975 and 1976. Biologisch Onderzoek Eems-Dollard Estuarium, Publikaties en Verslagen, 1978-1, p. 1-14

Colijn, F. (1982). Light absorption in the waters of the EmsDollard Estuary and its consequences for the growth of phytoplankton and microphytobenthos. Neth. J. Sea Res. 15 (2): 196-216

Colijn, F., van Buurt, G. (1975). Influence of light and temperature on the photosynthetic rate of marine benthic diatoms. Mar. Biol. 31: 209-214

Colijn, F., Dijkema, K. S. (1981). Species distribution of benthic diatoms and distribution of chlorophyll-a on an intertidal flat in the Dutch Wadden Sea. Mar. Ecol. Prog. Ser. 4: 9-21

Colijn, F., Gieskes, W. W. C., Zevenboom, W. (1983). Problems with the measurement of primary production: conclusions and Recommendations. Hydrobiol. Bull. 17 (1): $29-51$

Colijn, F., Venekamp, L. (1977). Benthic primary production in the Ems-Dollard Estuary during 1975. Hydrobiol. Bull. 11: $16-17$

Colocoloff, C. (1972). Recherches sur la production primaire d'un fond sableux. 1. Ecologie qualitative des Diatomées. Téthys 4 (3): 559-582

Connor, M. S., Teal, J. M., Valiela, I. (1982). The effect of feeding by mud snails, Ilyanassa absoleta (Say), on the structure and metabolism of a laboratory benthic algal community. J. exp. mar. Biol. Ecol. 65: 29-45

Darley, W. M., Lloyd Dunn, E., Susan Holmes, K., Larew, Hirman G., III (1976). A ${ }^{14} \mathrm{C}$ method for measuring epibenthic microalgal productivity in air. J. exp. mar. Biol. Ecol. 25: 207-217

Darley, W. M., Montague, C. L., Plumley, F. G., Sage, W W., Psalidas, A. T (1981). Factors limiting edaphic algal biomass and productivity in a Georgia salt marsh. J. Phycol. 17: 122-128

Eppley, R. W. (1981). Relations between nutrient assimilation and growth in phytoplankton with a brief review of estimates of growth rate in the ocean. In: Platt. I. (ed.) Physiological bases of phytoplankton ecology. Can. Bull. Fish. Aquat. Sci. 210: 251-263

Es, F. B. van (1982a). Community metabolism of intertidal flats in the Ems-Dollard estuary. Mar. Biol. 66: 95-108

Es, F. B. van (1982b). Some aspects of the flow of oxygen and organic carbon in the Ems-Dollard estuary. Biologisch 
onderzoek Eems-Dollard estuarium, Publicaties en Verslagen, 1982-5: 1-121

Es, F. B. van, Arkel, M. A. van, Bouwman, L. A., Schröder, H G. J. (1980). Influence of organic pollution on bacterial macrobenthic and meiobenthic populations in intertidal flats of the Dollard. Neth. J. Sea Res. 14 (3/4): 288-304

Fenchel, T., Staarup, B. J. (1971). Vertical distribution of photosynthetical pigments and the penetration of light in marine sediments. Oikos 22: 172-182

Gargas, E. (1970). Measurements of primary production, dark fixation and vertical distribution of the microbenthic algae in the Øresund. Ophelia 8: 231-253

Grontved, Jul. (1960). On the productivity of microbenthos and phytoplankton in some Danish fjords. Meddr Danm. Fisk-og Havunders., N. S. 3 (3) : 55-92

Grontved, Jul. (1962). Preliminary report on the productivity of microbenthos and phytoplankton in the Danish Wadden Sea. Meddr Danm. Fisk. og Havunders., N. S. 3 (12): $347-378$

Hall, S. L., Fisher, F. M., Jr (1982). Extracellular release of dissolved organic compounds by the epibenthic algal community of a Texas coastal marsh. Limnol. Oceanogr. Abstracts Ann. Meet., June 1982, p. 24

Hargrave, B. T., Prouse, N. J., Phillips, G. A., Neame, P. A. (1983). Primary production and respiration in pelagic and benthic communities at two intertidal sites in the upper bay of Fundy. Can. J. Fish. aquat. Sci. 40 (Suppl. 1): $229-243$

Hoek, C. van den, Admiraal, W., Colijn, F., De Jonge, V. N. (1979). The role of algae and seagrasses in the ecosystem of the Wadden Sea: a review. In: Wolff, W. J. (ed.) Flora and vegetation of the Wadden Sea. Report 3 of the Wadden Sea Working Group, Texel, The Netherlands, p. 9-118

Holmes, R. W., Mahall, B. E. (1982). Preliminary observations on the effects of flooding and desiccation upon the net photosynthetic rates of high intertidal estuarine sediments. Limnol. Oceanogr. 27 (5): 954-958

Hunding, C., Hargrave, B. T (1973). A comparison of benthic microalgal production measured by ${ }^{14} \mathrm{C}$ and oxygen methods. J. Fish. Res. Bd Can. 30: 309-312

Iverson, R. L., Bittaker, H. F., Myers, V. B. (1976). Loss of radiocarbon in direct use of Aquasol for liquid scintillation counting of solutions containing ${ }^{14} \mathrm{C}-\mathrm{NaHCO}_{3}$. Limnol. Oceanogr. 21 (5): 756-758

Joint, I. R. (1978). Microbial production of an estuarine mudflat. Estuar, coast. mar. Sci. 7: 185-195

Jonge, V. N. de (1983). The occurrence of epipsammic diatom populations: a result of interaction between physical sorting of sediment and some properties of diatom species. Estuar. coast. mar. Sci. (submitted)

Jonge, V. N. de, Postma, H. (1974). Phosphorus compounds in the Dutch Wadden Sea. Neth. J. Sea Res. 8: 139-153

Klein, B. (1981). Onderzoek aan de donker $\mathrm{CO}_{2}$ fixatie in de Grevelingenbodem: een nieuwe methode voor het meten van de $\mathrm{CO}_{2}$ fixatie in de bodem. Studentenverslag Delta Instituut voor Hydrobiologisch Onderzoek, 09-1981: 1-43

Leach, J. H. (1970). Epibenthic algal production in an intertidal mudflat. Limnol. Oceanogr. 15 (4): 514-521

Lindeboom, H. J., de Bree, B. H. H. (1982). Daily production and consumption in an eelgrass (Zostera marina) community in saline Lake Grevelingen: discrepancies between the $\mathrm{O}_{2}$ and ${ }^{14} \mathrm{C}$ method. Neth. J. Sea Res. 16: $362-379$

Lorenzen, C. J. (1967). Determination of chlorophyll and pheopigments: spectrophotometric equations. Limnol. Oceanogr. 12: 343-346

Marshall, N., Oviatt, A., Skauen, D. M. (1971). Productjvity of the benthic microflora of shoal estuarine environments in southern New England. Int. Revue ges. Hydrobiol. 56 (6) $947-956$

Marshall, N., Skauen, D. M., Lampe, H. C., Oviatt, C. A. (1973). Primary production of benthic microflora. In: A guide to the measurement of marine primary production under some special conditions. Unesco Monographs on Oceanographic Methodology 3: 37-44

Matheke, G. E. M., Horner, R. (1974). Primary productivity of the benthic microalgae in the Chukchi Sea near Barrow, Alaska. J. Fish. Res. Bd Can. 31 (11): 1779-1786

Pace, M. L., Shimmel, S., Darley, W M. (1979). The effect of grazing by a gastropod, Nassarius obsoletus, on the benthic microbial community of a salt marsh mudflat. Estuar. coast. mar. Sci. 9 (2): 121-134

Pamatmat, M. M. (1968). Ecology and metabolism of a benthic community on an intertidal sandflat. Int. Revue ges. Hydrobiol. 53 (2): 211-298

Peterson, B. J. (1980). Aquatic primary productivity and the ${ }^{14} \mathrm{C}-\mathrm{CO}_{2}$ method: a history of the productivity problem. Ann. Rev. Ecol. Syst. 11: 359-385

Plante-Cuny, M. R. (1973). Recherches sur la production primaire benthique en milieu marine tropical 1 Variations de la production primaire et des teneurs en pigments photosynthétiques sur quelques fonds sableux. Valuer des résultats obtenus par la méthode du ${ }^{14} \mathrm{C}$. Cah. O.R.S.T.O.M. sér. Océanogr. 11 (3): 317-348

Plante-Cuny, M. R. (1978). Pigments photosynthétiques et production primaire des fonds meubles méritiques d'une région tropicale (Nosy-Bé, Madagascar). Trav. Doc. l'O.R.S.T.O.M. $96: 1-359$

Pomeroy, L. R. (1959). Algal productivity in salt marshes of Georgia. Limnol. Oceanogr. 4 (4): 386-397

Raalte, C. van, Stewart, W. C., Valiela, I., Carpenter, E. J. (1974). A ${ }^{14} \mathrm{C}$ technique for measuring algal productivity in salt marsh muds. Botanica mar 17: 186-188

Raalte, C. D. van, Valiela, I., Teal, J. M. (1976). Production of epibenthic salt marsh algae: light and nutrient limitation. Limnol. Oceanogr 21 (6): 862-872

Revsbech, N. P., Jorgensen, B. B., Brix, O. (1981). Primary production of microalgae in sediments measured by oxygen microprofile, $\mathrm{H}^{14} \mathrm{CO}_{3}$-fixation, and oxygen exchange methods. Limnol. Oceanogr. 26 (4): 717-730

Revsbech, N. P., Jorgensen, B. B. (1983). Photosynthesis of benthic microflora measured with high spatial resolution by the oxygen microprofile method: capabilities and limitations of the method. Limnol. Oceanogr. (submitted)

Riznyk, R. Z., Edens, J. J., Libby, R. C. (1978). Production of epibenthic diatoms in Southern California impounded estuary. J. Phycol. 14: 273-279

Rutgers van der Loeff, M. M., van Es, F. B., Helder, W., de Vries, R. T. P. (1981). Sediment water exchanges of nutrients and oxygen on tidal flats in the Ems-Dollard estuary. Neth. J. Sea Res. 15: 113-129

Skauen, D. M., Marshall, N., Fragala, R. J. (1971). A liquid scintillation method for assaying ${ }^{14} \mathrm{C}$-labelled benthic microflora. J. Fish. Res. Bd Can. 28: 769-770

Steele, J. H., Baird, I. E. (1968). Production ecology of a sandy beach. Limnol. Oceanogr. 13 (1): 14-25

Steemann Nielsen, E. (1952). The use of radioactive carbon $\left({ }^{14} \mathrm{C}\right)$ for measuring organic production in the sea. J. Cons. perm. int. Explor. Mer 18: 117-140

Strickland, J. D. H., Parsons, T. R. (1972). A practical handbook of seawater analysis. Bull. Fish. Res. Bd Can. 167: $1-310$

Unesco Manual (1973). A guide to the measurement of marine primary production under some special conditions. Monographs on Oceanographic Methodology, Paris, 1973 
Williams, P. J. le B., Raine, R. C. T, Bryan, J. R. (1979). Agreement between the ${ }^{14} \mathrm{C}$ and oxygen methods of measuring phytoplankton production: reassessment of the photosynthetic quotient. Oceanol. Acta 2 (4): 411-416

This paper was submitted to the editor; it was accepted for printing on August 1, 1983 